\title{
Electronic Source Report Form
}

National Cancer Institute

\section{Source}

National Cancer Institute. Electronic Source Report Form. NCI Thesaurus. Code C142537.

A digital form that is used to capture and manage original data. 